\title{
OPTIMALISASI SUPERVISI PENDIDIKAN TERHADAP PENINGKATAN KUALIFIKASI DAN KOMPETENSI GURU UNTUK PENINGKATKAN KUALITAS PENDIDIKAN INDONESIA
}

\author{
Oleh : Ataya Aufa Saleh \\ E-mail : atayaaufasaleh@gmail.com
}

\begin{abstract}
ABSTRAK
Permasalahan pendidikan yang dihadapi di Indonesia sangat komplek yang mengakibatkan tidak meningkatnya kualitas pendidikan di Indonesia secara signifikan. Salah satu masalah yang ada yaitu kualifikasi dan kompetensi guru yang masih rendah. Guru memegang peranan penting dalam kegiatan belajar mengajar yang sangat berhubungan dengan kualitas pendidikan. Untuk itu, optimalisasi supervisi pendidikan sangat dibutuhkan agar dapat meningkatkan kualifikasi dan kompetensi guru dan pada akhirnya berdampak pada peningkatan kualitas pendidikan di Indonesia.
\end{abstract}

Kata Kunci : supervisi pendidikan, kualifikasi dan kompentensi guru

\section{Latarbelakang Masalah}

Pendidikan adalah salah satu parameter pengukur kemajuan suatu Negara. Apabila kualitas pendidikan suatu Negara terbilang baik maka pembangunan di Negara tersebut akan cepat dan dinamis karena kualitas SDM yang memadai. Pendidikan adalah investasi besar untuk mencetak sumber daya manusia yang berkualitas untuk menentukan nasib bangsa kedepannya. Namun lain dengan Indonesia, masih banyak problematika dunia pendidikan yang membuat tidak optimalnya peningkatan kualitas sumber daya manusia (SDM) . Beberapa problematika pendidikan adalah (1) Pendidikan yang belum merata (2) Sarana \& Prasarana pendidikan yang kurang memadai (3) Kualifikasi guru yang masih rendah (4)Beban kerja guru yang tidak proporsional dan masih banyak lainnya.

Pada pasal 8 UU No. 14 tahun 2005 tentang Guru dan Dosen menyatakan bahwa guru wajib memiliki kualifikasi akademik, kompetensi, sertifikat pendidik, sehat jasmani dan rohani, serta memiliki kemampuan untuk mewujudkan tujuan pendidikan nasional. Pada pasal 20 UU No. 14 tahun 2005 juga menyatakan bahwa guru mempunyai kewajiban untuk terus meningkatkan kualifikasi akademik dan kompetensi secara berkelanjutan sejalan dengan perkembangan IPTEK sesuai Oleh karena itu, dibutuhkan supervisi pendidikan yang dapat menfasilitasi dan mengarahkan guru untuk meningkatkan kualifikasi dan 
kompetensinya tersebut. Guru yang berkualitas akan menciptakan peserta didik yang berkualitas pula. Untuk itu, aspek guru/tenaga pendidik juga patut dipertimbangkan dalam hal peningkatan kualitas pendidikan di Indonesia.

Supervisi pendidikan di Indonesia sendiri juga masih belum optimal sepenuhnya. Masih banyak problematika yang dihadapi seperti (1) Kurangnya kesadaran guru akan pentingnya supervisi. Pada perspektif guru, supervisi hanya seperti intervensi dari para supervisor sehingga kurang adanya respon yang baik. (2) Kepala sekolah atau pengawas sebagai supervisor mempunyai pandangan bahwa guru punya otonomi sendiri dan pasti sudah tahu apa yang harus dilakukan atau diperbaiki sehingga supervisor seringkali melakukan supervisi hanya semata-mata sebagai tugas. (3) Kompetensi supervisor yang belum sesuai standar kompetensi seharusnya (4) Jumlah supervisor yang masih terbatas dan tidak seimbang dengan jumlah guru keseluruhan.

Untuk itu berdasarkan latarbelakang yang telah dipaparkan perlu dirumuskan masalah yaitu bagaimana cara atau teknik supervisi pendidikan yang optimal terkhusus bagi peningkatan kualitas guru untuk mencapai peningkatan mutu pendidikan di Indonesia.

\section{Tujuan}

Tujuan penulisan ini selain untuk memenuhi tugas perkuliahan Administrasi Pendidikan adalah untuk memberitahukan teknik-teknik/ cara-cara bagaimana supervisi pendidikan lebih optimal untuk peningkatan mutu pendidikan khusunya dampak supervisi pendidikan terhadap peningkatan kualifikasi dan kompetensi guru.

\section{Pembahasan}

Menurut Drs. Ary H. Gunawan (Gunawan, 2002), dalam pelaksanaan supervisi pendidikan terlibat adanya berbagai ragam/corak seperti : (1) Supervisi yang preventif yang berarti supervisor memberikan saran dan nasihat agar mencegah kesalahan-kesalahan atau kesulitan yang mungkin terjadi. Supervisi yang korektif yang berarti supervisi lebih banyak mencari kesalahan guru yang ia supervisi. (3) Supervisi yang konstruktif yang berarti supervisor lebih banyak memberikan kritik yang membangun dan berusaha memotivasi dan membangkitkan semangat guru yang ia supervisi (4) Supervisi yang kreatif berarti supervisor lebih menekankan pada inisiatif daya cipta, penelitian dan prestasi bawahannya dengan memberikan penghargaan. (5) Supervisi yang kooperatif yang berarti supervisor mengutamakan kerjasama, partisipasi, musyawarah toleransi dengan orang yang ia supervisi 
demi peningkatan kualitas pendidikan. Dari ragam/corak supervisi diatas, hendaknya para supervisor dapat menyesuaikan dengan yang dibutuhkan dilapangan dan kebutuhan guru masing-masing.

Menurut Ahmad Sabandi (Sabandi, 2013) , supervisor dapat menggunakan berbagai pendekatan untuk meningkatkan kualifikasi dan kompetensi guru yaitu (1) Teknik supervisi yang meliputi :

a. supervisi klinis yang berarti guru dan supervisor saling bertemu dan membahas masalah pembelajaran yang terjadi dikelas.

b. supervisi pengembangan yang berarti menempatkan guru pada tahap pertumbuhan dan pengembangan yang mana menyatakan setiap guru mempunyai pengalaman dan kemampuan yang berbeda-beda sehingga supervisi dilakukan berdasarkan kebutuhan guru masingmasing.

c. Supervisi differensial merupakan pendekatan supervisi yang baru. Pendekatan ini menyediakan pilihan jenis supervisi dan evaluasi yang disesuaikan dengan kebutuhan guru sehingga lebih fleksibel

(2) Kegiatan pelatihan yang akan meningkatkan kualifikasi dan kompetensi guru. Pelatihan ini dapat dilakukan dalam berbagai bentuk yaitu orientasi, kuliah, bermain peran dan simulasi, metode audiovisual, perluasan pekerjaan, magang, pembelajaran terprogram,pelatihan laboratorium, dan pelatihan kelas dan konferensi. (3) Menciptakan budaya organisasi pembelajaran berarti menumbuhkan sikap guru untuk mempunyai komitmen kuat terhadap peningkatan kualitas dan kompetensi dirinya dan melaksanakan tugas secara lebih terarah untuk meningkatkan kualitas pembelajaran.

Menurut M.Ngalim Purwanto (Purwanto, 2009) teknik supervisi dapat dibedakan menjadi dua yaitu teknik perserorangan dan teknik kelompok. Untuk teknik perseorangan, kegiatan yang dapat dilakukan yaitu (1) mengadakan kunjungan kelas (classroom visition) tujuannya untuk mengobservasi guru yang sedang mengajar apakah sudah memenuhi standar proses yang ada. (2) mengadakan kunjungan observasi yang berupa kegiatan guru-guru dari suatu sekolah ditugaskan mengamati guru lain yang sedang mendemonstrasikan cara-cara mengajar. (3) membimbing guruguru untuk mengatasi masalah yang dialami siswa dan mempelajari cara mengenali karakter siswa itu sendiri (4) membimbing guru-guru dalam hal yang berhubungan dengan pelaksanaan kurikulum sekolah. Untuk teknik kelompok, kegiatan yang dilakukan adalah (1) mengadakan pertemuan atau rapat yang membahas masalah-masalah yang terjadi dikelas (2) 
mengadakan diskusi kelompok yang membicarakan tentang usaha pengembangan proses belajar mengajar (3) mengadakan penataran-penataran.

\section{Kesimpulan \& Saran}

Optimalisasi supervisi pendidikan dapat dilakukan dengan berbagai cara dan pendekatan untuk meningkatkan kualifikasi dan kompetensi guru. Salah satu aspek untuk peningkatan mutu pendidikan adalah peningkatan kualitas guru itu sendiri sehingga sangat dibutuhkan optimalisasi supervisi pendidikan. Berbagai pendekatan yang dapat dilakukan diantaranya adalah menerapkan teknik supervisi, kegiatan pelatihan, dan menciptakan budaya organisasi pembelajaran. Selain itu teknik supervisi dibedakan menjadi dua yaitu teknik perseorangan yang meliputi kegiatan kunjungan kelas, kunjungan observasi, dan bimbingan terhadap guru. Sedangkan, teknik kelompok yaitu mengadakan pertemuan atau rapat, mengadakan diskusi kelompok dan mengadakan penataranpenataran.

\section{Referensi}

Gunawan, A. (2002). Administrasi Sekolah

(Administrasi Pendidikan Mikro). Jakarta: Rineka Cipta.

Purwanto, M. N. (2009). Prinsip-prinsip dan Teknik Evaluasi Pengajaran. Bandung:
Remaja Rosdakarya.

Sabandi, A. (2013). Supervisi Pendidikan Untuk Pengembangan Profesionalitas Guru Berkelanjutan. Jurnal Ilmiah Ilmu Pendidikan, XIII(2), 1-9. Retrieved from http://ejournal.unp.ac.id/index.php/pedag ogi/article/view/4275 